\title{
PERFORMANCE EVALUATION OF A MILLING MACHINE FOR PRODUCING BROILER PELLET CRUMBLES
}

\author{
Hanan, M.S. El-Shal*
}

\begin{abstract}
The goal of this study is evaluating some operating parameters affecting performance of a roller mill and the particle size distribution during producing broiler crumbled feeds $(\mathrm{CF})$ from poultry pellets for the phase of starter. These pellets were manufactured from standard formulation including ingredients with percentages that recommended to the broiler starter. The performance of the milling machine was evaluated under operational variables including; four different roller rotational speeds of 350, 400, 466.67 and 560 rpm corresponding to 2.75, 3.14, 3.66 and 4.40 $\mathrm{m} / \mathrm{s}$, three roll clearances of $1.5,2.5$ and $3.5 \mathrm{~mm}$, three feeding rates of 1.3, 4.1 and $6.8 \mathrm{Mg} / \mathrm{h}$. The performance of the machine was evaluated taking into consideration the machine capacity, particle size distribution of the CF, and energy requirement. The obtained results reveal that, it is recommended to use the roller mill at roll speed of $466.67 \mathrm{rpm}(3.66 \mathrm{~m} / \mathrm{s})$, feeding rate of $6.80 \mathrm{Mg} / \mathrm{h}$ and roll clearance of $1.50 \mathrm{~mm}$ to achieve the best CF particle size distribution $(<1 \mathrm{~mm}=19.45 \%,>1 \mathrm{~mm}=29.46 \%$, $>2 \mathrm{~mm}=38.64 \%$ and $>3 \mathrm{~mm}=12.45 \%)$ that suit the broiler in the phase of starter at machine capacity of $5.650 \mathrm{Mg} / \mathrm{h}$ and consumed energy of about $0.476 \mathrm{~kW} . \mathrm{h} / \mathrm{Mg}$.
\end{abstract}

Keywords: roller mill, broiler, crumbled feeds, particle size distribution, roll clearance

\section{INTRODUCTION}

$\mathrm{t}$ is Known that the most of recent investigations are focusing on how
to minimize the total cost of the broiler production by reducing the
losses and consequently the cost of the processing operations of the manufactured feeds such as pellets, crumbles or even mash feed .Moreover, selecting the proper diet in the acceptable phase of broiler could improve the feed conversion and enhance the growth performance.

"Lecturer, Agric. Eng. Dept., Fac. of Agric., Zagazig Univ., Egypt. 
The cost of feed is a primary concern to the poultry industry since it is compromises about $60-70 \%$ of the total cost of broiler production (Banerjee, 1998). The physical form of feed (mash, pellet and crumble) is a key factor in meat yield of broiler (Mohamed and Talha, 2012). The feeding of pellets improves feed conversion broiler performance (Behnke, 1994) with an increased feed intake (Nir $\boldsymbol{e t}$ al., 1995).Reasons for the enhanced performance may be due to increased digestibility, decreased ingredient segregation, decreased feed wastage, reduction of energy during prehension and improved palatability (Behnke, 1998). There are three growing phases of the broiler, the starter (0-14 day), the grower (15-35 day) and the finisher (35-42 day). The final bodyweight performance is positively correlated with early growth rate (e.g. 7day body weight); thereby ensuring chicks get off to a good start is critical (Aviagen, 2014). Crumbles is become a convenience method for enhancing the growth performance the starter broiler is a type of feed prepared at the mill by pelleting of the mixed ingredients and then crushing the pellet to a consistency coarser than mash (Jahan et al., 2006). Two processing methods are commonly used to reduce the particle size of the grains; the hammer mill and the roller mill (Waldroup, 1997). Reducing feed particles to a finer size requires greater energy use and lowers production rate. Thus, any reduction in energy consumption from grinding could significantly lower feed cost (Dozier, 2002).Roller mills are more efficient and require less energy for grinding than the hammer mill also, the roller mill produces a more uniform particle size distribution with lower a proportion of fines than the hammer mill (Nir and Ptichi, 2001). Due to the significantly lower energy cost per ton, the roller mill offers an overall lower cost. Regarding these advantages, this study is concerning to utilize the roller mill for crumbling the pellets to feed the broiler starter in attempt to reduce the consumed energy with most appropriate particle size distribution of the crumbled feed. So, the objectives of this study are:

1- Evaluating a local made roller mill for crumbling the processed pellets to feed the broiler starter.

2- Studying some operating parameters affecting performance of the roller mill and the particle size distribution that suit the broiler starter. 
3- Determining the consumed energy of the roller mill during crumbling process.

\section{MATERIALS AND METHODS}

The practical experiments were performed in a private poultry pellet feed factory at Abou Hammad district, Sharkia Governorate to evaluate the performance of a roller mill for producing broiler (Starter ) crumbles.

\section{A-Materials:}

\section{-The poultry pellets:}

The poultry pellets were manufactured using a ring die pelleting with diameter of $3 \mathrm{~mm}$ and length of $6 \mathrm{~mm}$. The die of the pelleting machine with $200 \mathrm{~mm}$ in diameter and $40 \mathrm{~mm}$ in thickness was operated at speed of $350 \mathrm{rpm}$, whereas the roller diameter was $90 \mathrm{~mm}$. The moisture was added to the formulation as steam in the conditioner. The percentages of the ingredients in the broiler starter formulation are given in Table (1).

Table (1): The ingredients of the broiler starter formulation

\begin{tabular}{|l|c|}
\hline \multicolumn{1}{|c|}{ Ingredients } & Percentage, $\%$ \\
\hline Yellow Corn & 58.50 \\
\hline Soy Meal & 30.50 \\
\hline Soy oil & 2.50 \\
\hline Dicalcium & 1.80 \\
\hline Calcium Carbonate & 0.97 \\
\hline Salt & 0.25 \\
\hline Vit/Minerals & 0.30 \\
\hline Gluten & 4.58 \\
\hline Methionine & 0.20 \\
\hline Lysine & 0.20 \\
\hline Threonine & 0.10 \\
\hline Antitoxin & 0.10 \\
\hline Total & 100 \\
\hline
\end{tabular}

\section{-The roller mill:}

The roller mill was used to crumbling the produced pellets to reduce their size because the broiler starter feeds, and often the first delivery of broiler grower feeds, are usually crumbles. The construction features of the 
milling machine mainly consists of the following parts as shown in Figs.(1and 2):

\section{- The machine hopper and frame}

It is a galvanized steel hopper with trapezoidal sectional profile with 3 $\mathrm{mm}$ in thickness, $2.5 \mathrm{~mm}$ in length, $1125 . \mathrm{mm}$ at top and $875 \mathrm{~mm}$ at bottom with width of $675 \mathrm{~mm}$ at top and $550 \mathrm{~mm}$ at bottom and $220 \mathrm{~mm}$ in depth. There is a folding gate at the bottom of the hopper to control flow rate of the pellets that passing through it, in addition to assure the longitudinal distribution of pellets along the crushing rolls. Regarding frame, it is a robust rectangular box frame that made of steel with geometric dimension of $1175 \mathrm{~L} \times 550 \mathrm{~W} \times 725 \mathrm{D} \mathrm{mm}$, which accommodate a pair of crushing rolls and secure their position during operating.

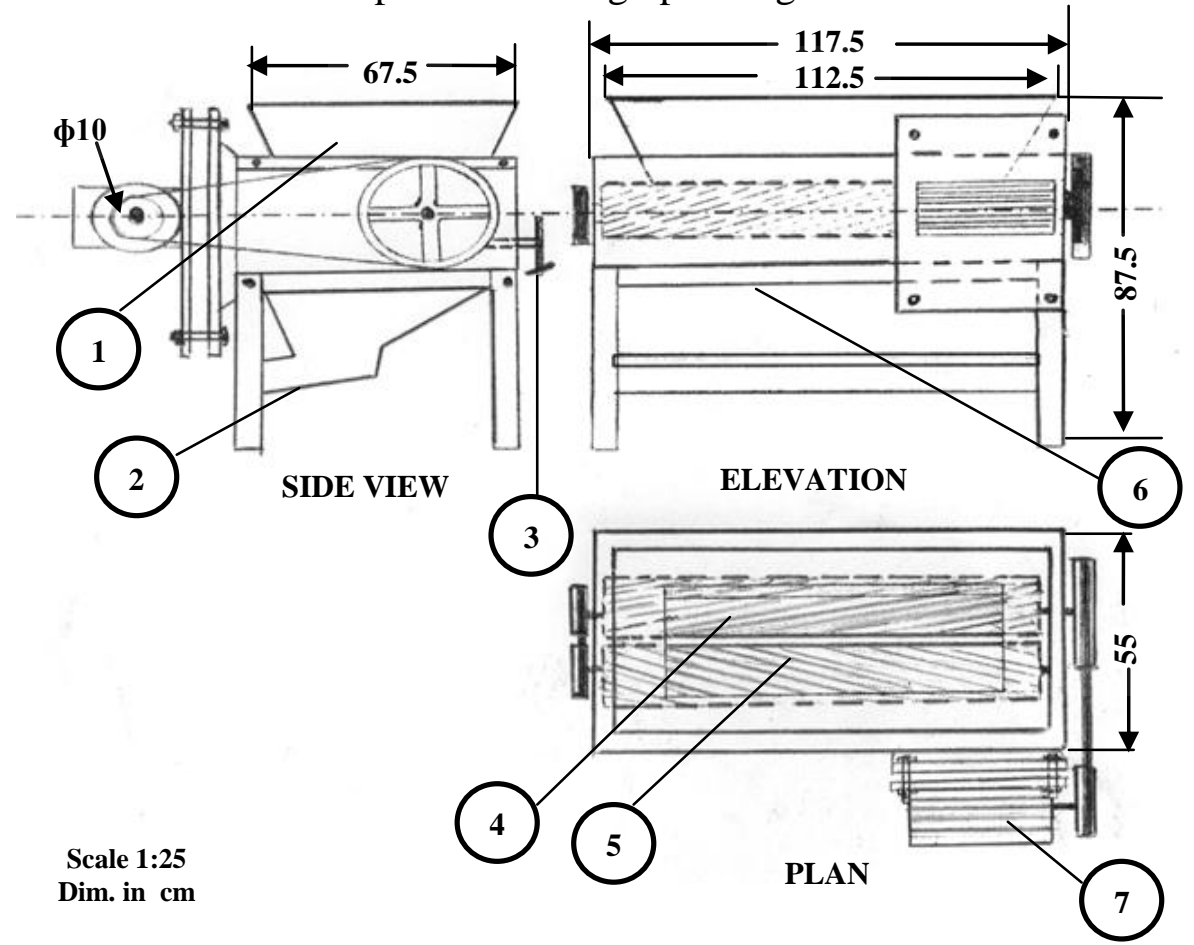

(1) Feed hopper, (2) Outlet chute, (3) roll clearance adjustment screw, (4) Drive roll, (5) Driven roll, (6) Frame, (7) Electric motor.

Fig. (1): Elevation, plan and side view of the roller mill.

\section{- Crushing rolls}

The milling machine consists of two steel corrugated in parallel and tram rolls (as shown in Fig.3-a) with $150 \mathrm{~mm}$ in diameter and $1100 \mathrm{~mm}$ in 
length, where one of the rolls (drive roll) received the motion from an electric motor from one side of the frame, while the opposite one (driven roll) takes its rotational motion from the drive roll at the other side of frame by using pulley and belts transmission unit. The roll corrugation can be described as roll fluting, where the two rolls were corrugated circumferentially with grooves known as the LaPage ring cut and it can featured as classical LaPage ring cut, as shown in Fig.(3-b). The clearance between two rolls can be adjusted through pressing on the driver roll by perpendicular screw, while the opposite roll remained fixed.

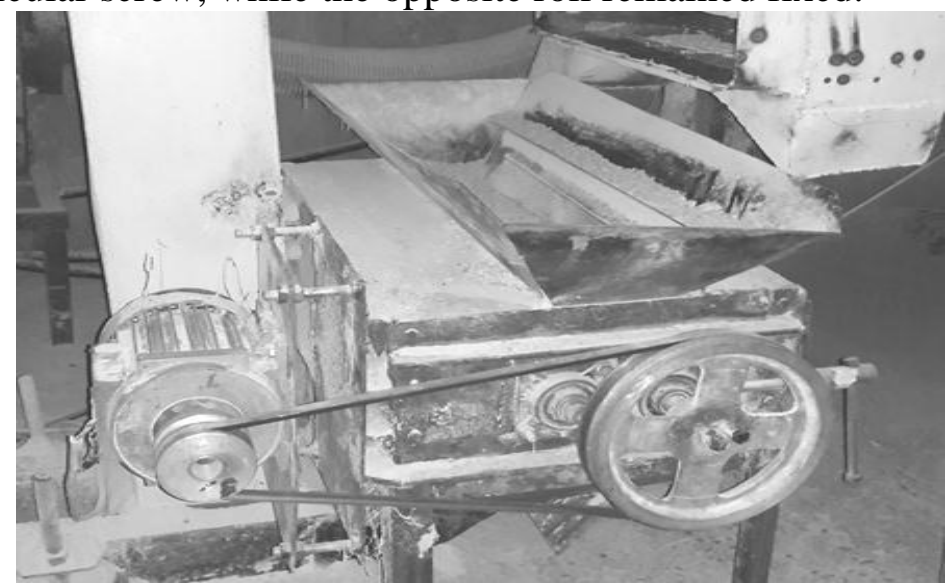

Fig.(2): View of the roller milling machine.

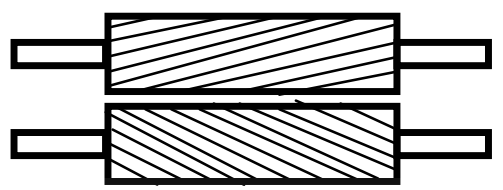

Rolls in Parallel

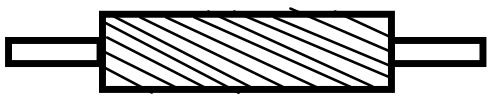

Rolls in Tram

(Front View)

(Top View)

$a$-The rolls position within machine

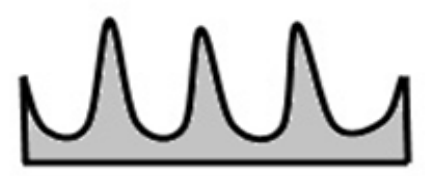

$b$ - The LaPage ring cut profile

Fig. (3): The shape, position and grooves profile of rolls. 


\section{- Power Unit}

The power unit including electric motor that fixed on the machine frame with rated power of $5 \mathrm{~kW}$ at $1400 \mathrm{rpm}$ rotational speed. It was used to operate the drive roll through pulley and belt unit. In this study four pulley's diameters were used of $250,300,350$ and $400 \mathrm{~mm}$ to obtain four roll rotational speeds of 350, 400, 466.67 and $560 \mathrm{rpm}$, respectively, as shown in Fig.(4).

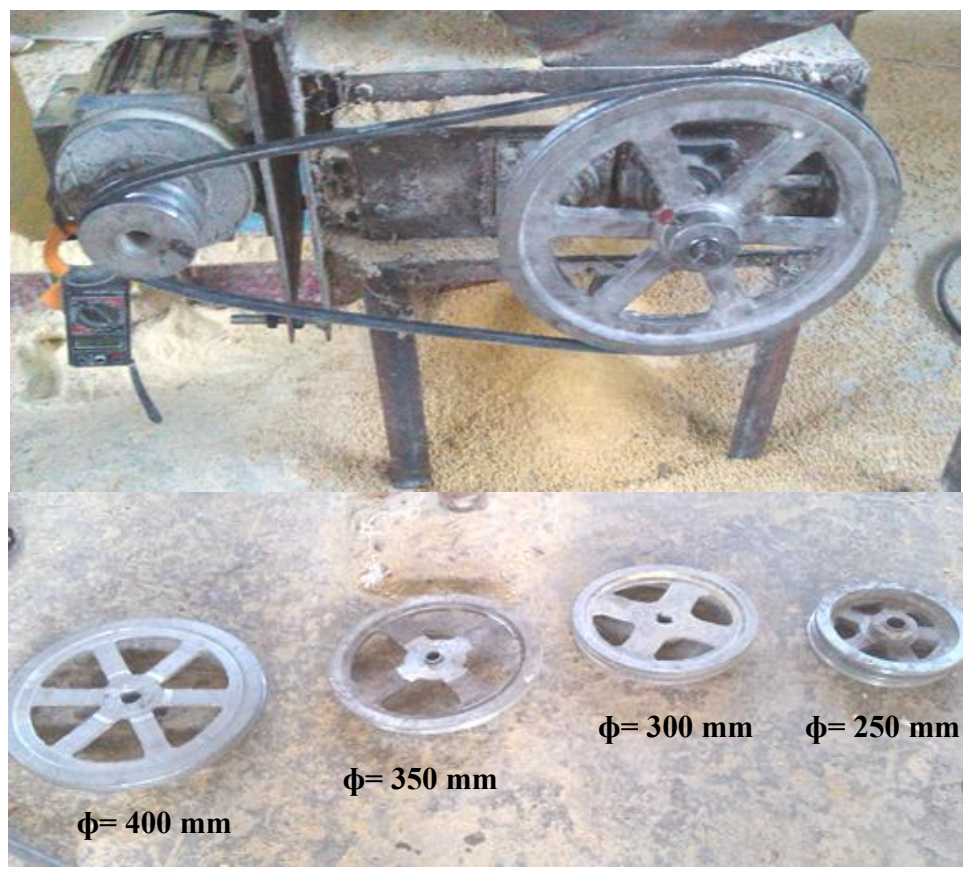

Fig.(4): The transmission unit using different pulley's diameters.

\section{- Crumbles Sieving}

Motorized, sieve shaker (HUMBOLDT .MFG .Co, USA, Model: H-4325) with dimension of $380 \times 380 \times 1143 \mathrm{~mm}$ uses a $1 / 4 \mathrm{hp}$ electric motor with a 30-minute timer. In this study, four sieves of $0.5,1,2,3 \mathrm{~mm}$ plus the cover and pan were used to determine the particle size distribution in the crumbled feed (CF), as shown in Fig.(5).

\section{B-Methods:}

The practical experiments were carried out to select the proper operating parameters affecting the performance of the roller mill, these parameters are: 
1- Four roll speeds of 350, 400, 466.67 and $560 \mathrm{rpm}$ that corresponding peripheral speeds of $2.75,3.14,3.66$ and $4.40 \mathrm{~m} / \mathrm{s}$.

2- Three feeding rates of $1.300,4.100$ and $6.800 \mathrm{Mg} / \mathrm{h}$.

3-Three levels for rolls clearance of 1.5, 2.5 and $3.5 \mathrm{~mm}$.

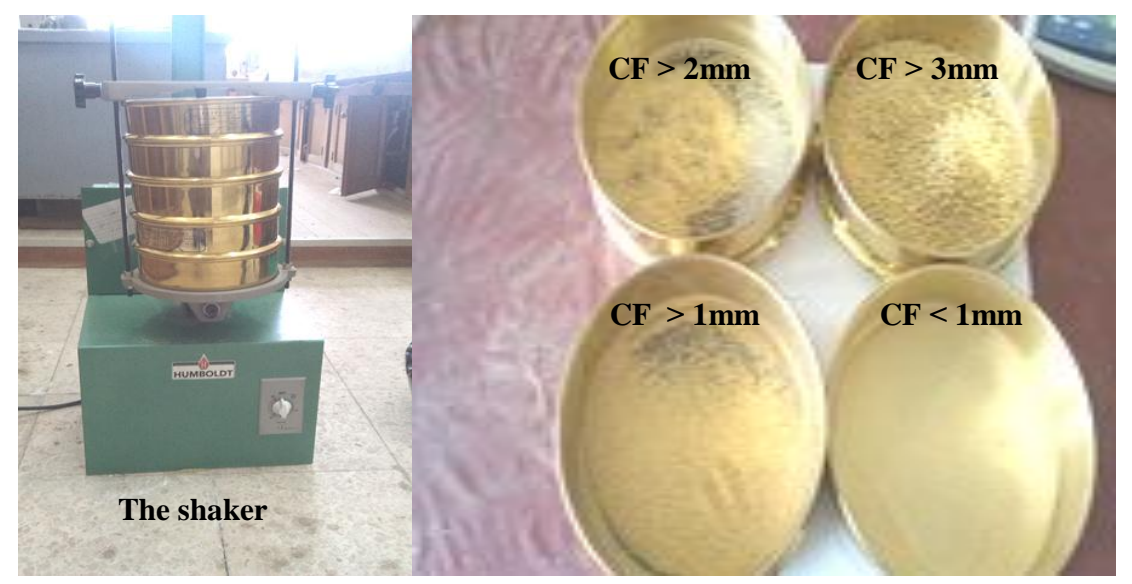

Fig.(5): The shaker and sieves.

\section{- MEASUREMENTS:}

\section{Milling capacity}

The actual milling capacity $(\mathrm{Mg} / \mathrm{h})$ of the machine is the actual rate of productivity by the amount of actual time consumed in operation.

\section{Particle size distribution:}

The recommended particle size distribution of crumbled feeds (CF) in broiler starter diet is shown in Table (2). Trials have shown that every $10 \%$ increase in fines $(<1 \mathrm{~mm})$ results in a reduction of $40 \mathrm{~g}$ body weight at 35 days, and therefore, the aim should be to minimize the amount of fine particles $(<1 \mathrm{~mm})$ in the crumble feed (Aviagen, 2014).

Table (2): Recommended particle size distribution of $\mathrm{CF}$ according to (Aviagen, 2014)

\begin{tabular}{|c|c|}
\hline Size & Feed form \\
\hline$>3 \mathrm{~mm}$ & $15 \%$ \\
\hline$>2 \mathrm{~mm}$ & $40 \%$ \\
\hline$>1 \mathrm{~mm}$ & $35 \%$ \\
\hline$<1 \mathrm{~mm}$ & $<10 \%$ \\
\hline
\end{tabular}




\section{Power and energy requirement:}

The required milling power was calculated by using the following equation:

Consumed Power, $k W=\frac{\sqrt{3} I \cdot V \eta \cos \theta}{1000}$

Where:

$\mathrm{I}=$ line current strength in Amperes.

$\mathrm{V}=$ Potential strength (voltage) being equal to $390 \mathrm{~V}$.

$\cos \theta=$ power factor (being equal to 0.84 ).

$\eta$ = Mechanical efficiency assumed (95\%).

The specific energy requirement $(\mathrm{kW} . \mathrm{h} / \mathrm{Mg})$ was calculated by using the following relation:

The specific energy requirement, $\mathrm{kW} \cdot \mathrm{h} / \mathrm{Mg}=\frac{\text { The consumed power }(\mathrm{kW})}{\text { Actual machine capacity }(\mathrm{Mg} / \mathrm{h})}$

\section{RESULTS AND DISCUSSION}

\section{- Roller mill capacity:}

Fig. (6) describe the relation between roll speed and the actual machine capacity under different feeding rates and roll clearances. It was observed that, machine capacity increased by increasing the roll speed, roll clearance and feeding rate. Regarding relation between feeding rate and the actual machine capacity, the obtained results show that, increasing feeding rate from 1.3 to $6.8 \mathrm{Mg} / \mathrm{h}$, the highest machine capacity at roll speed of $560 \mathrm{rpm}(4.40 \mathrm{~m} / \mathrm{s})$ and roll clearance $3 \mathrm{~mm}$ was increased from 1.298 to $6.797 \mathrm{Mg} / \mathrm{h}$ whereas, the lowest machine capacity at roll speed of $350 \mathrm{rpm}(2.75 \mathrm{~m} / \mathrm{s})$ and roll clearance $1.50 \mathrm{~mm}$ was increased from 0.630 to $5.713 \mathrm{Mg} / \mathrm{h}$. This expected because the high rate of feeding could create a considerable and rapid accumulation in the clearance between the rotating rolls. Fig. (6) display that, lowest value of machine capacity recorded at roll speed of $350 \mathrm{rpm}$, feeding rate of $1.30 \mathrm{Mg} / \mathrm{h}$ and roll clearance of $1.50 \mathrm{~mm}$ while, he highest value of machine capacity recorded at roll speed of $560 \mathrm{rpm}$, feeding rate of $6.8 \mathrm{Mg} / \mathrm{h}$ and rolls clearance of $3.50 \mathrm{~mm}$. It was noticed that, the increase of roll speed from 466.67 to $560 \mathrm{rpm}$ accompanied with a very slight increase in machine capacity, especially at high feeding rates of 4.1 and $6.8 \mathrm{Mg} / \mathrm{h}$ and wide roll clearances of 2.50 and $3.50 \mathrm{~mm}$. 

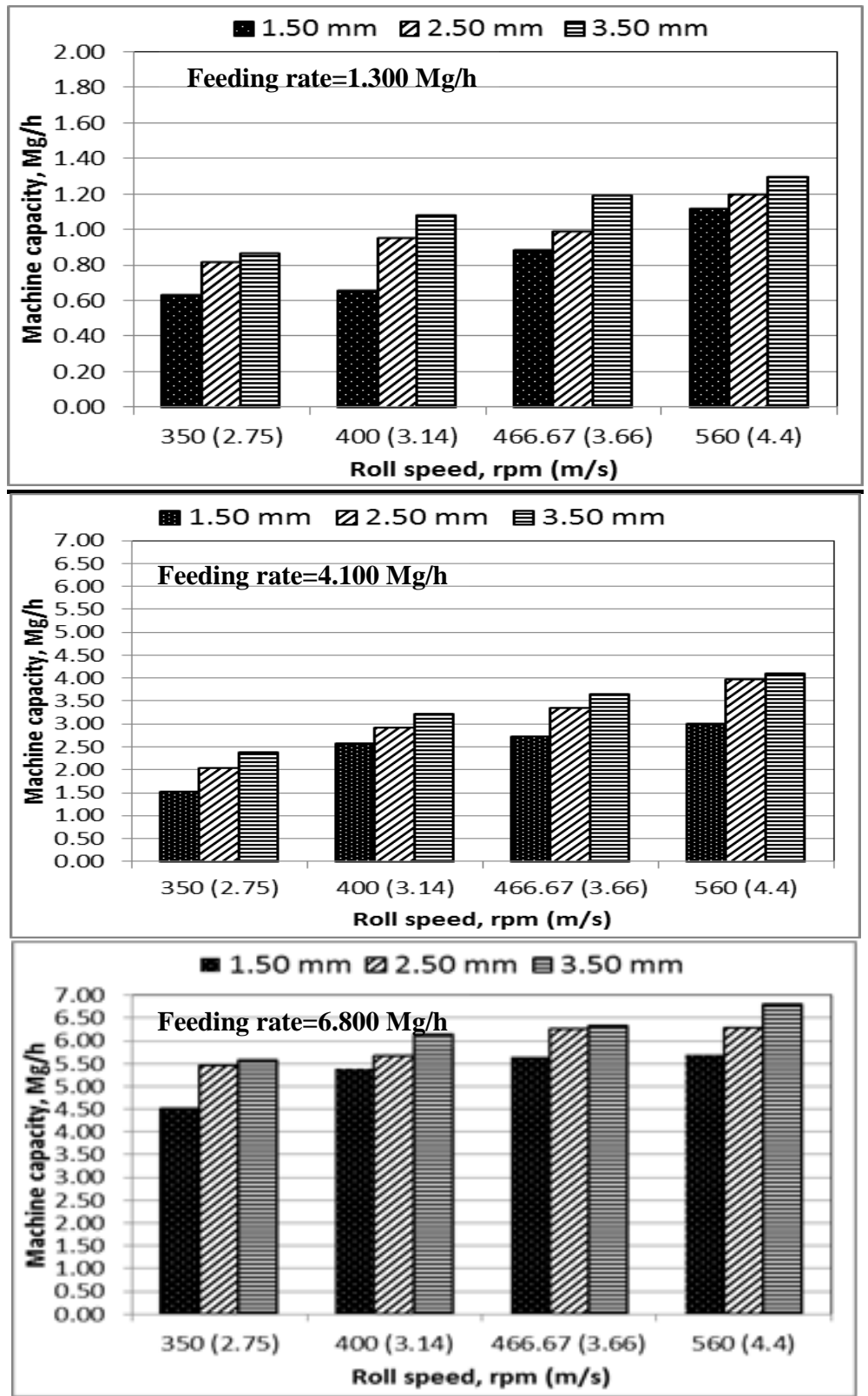

Fig.(6): Effect of rolls speed and feeding rate on the machine capacity using different roll clearances.

This can be attributed to the resistance of the huge quantity of pellet to the rotating rolls through the clearance that can lead to increase the milling time relatively and consequently reduce the capacity at the high roll speed of $560 \mathrm{rpm}$.The rolls clearance is playing an important rule to increase 
the machine capacity clearly especially at high feeding rates. Hence, the highest value of machine capacity of $6.799 \mathrm{Mg} / \mathrm{h}$ was obtained at roll speed of $560 \mathrm{rpm}(4.40 \mathrm{~m} / \mathrm{s})$ and rolls clearance of $3.5 \mathrm{~mm}$, whereas the lowest value of machine capacity of $0.630 \mathrm{Mg} / \mathrm{h}$ was recorded at roll speed of $350 \mathrm{rpm}(2.75 \mathrm{~m} / \mathrm{s})$ and roll clearance of $1.5 \mathrm{~mm}$.

\section{- Particle size distribution of the crumbled feeds (CF):}

Table (3) shows the particle size distribution of the crumbled feeds (CF) using different roll speeds, feeding rates and roll clearances. It was clear that, the best crumbled feed (CF) particle size distribution has been obtained as follows: $\mathrm{CF}<1 \mathrm{~mm}=19.45 \%, \mathrm{CF}>1 \mathrm{~mm}=29.46 \%, \mathrm{CF}>2 \mathrm{~mm}=$ $38.64 \%$ and $\mathrm{CF}>3 \mathrm{~mm}=12.45 \%$, at roll speed of $466.67 \mathrm{rpm}(3.66 \mathrm{~m} / \mathrm{s})$, feeding rate of $6.800 \mathrm{Mg} / \mathrm{h}$ and roll clearance of $1.50 \mathrm{~mm}$, as shown in Fig.(7) .This distribution is very close to the particle size distribution that suit the broiler in the phase of starter that recommended by (Aviagen, 2014). Regarding the best distribution of the crumbled feeds $(\mathrm{CF})$ particle size, the low roll clearance, high feeding rate and roll speed gave a relatively low percentages for both the fine $(\mathrm{CF}<1 \mathrm{~mm})$ and coarse $(\mathrm{CF} \geq$ $3 \mathrm{~mm})$ particles, while the medium particles $(\mathrm{CF}>1 \mathrm{~mm}$ and $\mathrm{CF}>2 \mathrm{~mm})$ would increase, despite, it was expected that the small clearance would give more fines and low coarse of the CF. This can be attributed to the high accumulation of the pellets feed that occurred in the tiny roll clearance at the high feeding rate and high roll speed which leads to enlarge this clearance under the effect of the spring compression of the clearance adjustment screw, then the particle sizes of the $\mathrm{CF}$ will concentrate in the medium size category of the distribution.

\section{-Energy requirement:}

The relation between roll speed and specific energy requirement under different feeding rates and roll clearances is illustrated in Fig.(8). It was noticed that, the increase of roll speed, feeding rate and roll clearance would decrease the specific energy requirement for crumbling the broiler pellets. This is because the increase that occurred of machine capacity is higher than increase in power required rate, in addition to the low resistance of the pellets to the rotation of rolls during passing through the clearance at the highest values of roll speed, feeding rate and roll clearance. 


\begin{tabular}{|c|c|c|c|c|c|c|c|c|c|c|c|c|}
\hline \multirow{16}{*}{ 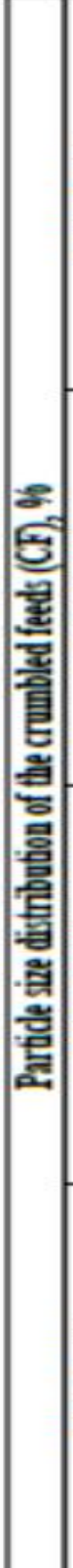 } & \multirow{4}{*}{$\begin{array}{c}\text { 慁 } \\
\frac{\mathrm{v}}{\mathrm{E}}\end{array}$} & \multirow{4}{*}{ 蒠 } & 80 & $\stackrel{2}{\tilde{z}}$ & $\tilde{z}$ & 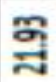 & 学 & $\widetilde{\widetilde{\Omega}}$ & 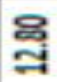 & 总 & $\approx$ & 응 \\
\hline & & & $\frac{6}{8}$ & 営 & 㤀 & 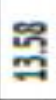 & $\begin{array}{l}\text { g: } \\
\text { 号 }\end{array}$ & 尔 & โ2 & 乌ั & 疍 & 辰 \\
\hline & & & 胥 & : & 용 & ఇี & 胥 & $\stackrel{2}{\beth}$ & $\underset{\mathrm{S}}{\overrightarrow{\mathrm{O}}}$ & 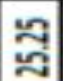 & 응 & g \\
\hline & & & 压 & $\overrightarrow{8}$ & $\begin{array}{l}98 \\
00\end{array}$ & 总 & $\begin{array}{l}8 \\
8\end{array}$ & 옹 & 곡 & $\vec{z}$ & $\begin{array}{l}\mathscr{8} \\
\text { ؟ }\end{array}$ & 号 \\
\hline & \multirow{4}{*}{ 慁 } & \multirow{4}{*}{ 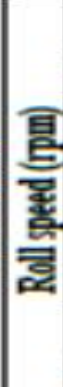 } & 8 & $\frac{3}{8}$ & 을 & $\underset{\not ్}{\not ్}$ & $\frac{\mathbb{2}}{8}$ & 용 & 胥 & 유ํ & 丞 & 㞼 \\
\hline & & & $\frac{5}{8}$ & శ్శి & 를 & 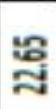 & $\begin{array}{l}8 \\
\text { : }\end{array}$ & $\stackrel{8}{\mathcal{8}}$ & $\underset{\text { 월 }}{\overrightarrow{2}}$ & ฉึ & 疍 & 㗊 \\
\hline & & & \$ & $\begin{array}{l}8 \\
8 \\
9\end{array}$ & ${ }_{m}^{8}$ & ฉี & $\begin{array}{l}\text { : } \\
\text { m }\end{array}$ & $\frac{\mathbb{2}}{\tilde{z}}$ & 疍 & 兽 & $\underset{7}{8}$ & : \\
\hline & & & 屋 & 胥 & 旁 & 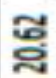 & $\begin{array}{l}\vec{b} \\
\vec{j}\end{array}$ & 을 & ه্: & $\underset{m}{\approx}$ & 悤 & \% \\
\hline & \multirow{4}{*}{ 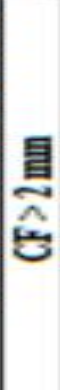 } & \multirow{4}{*}{ 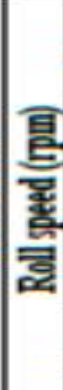 } & 8 & ్ㅗㄱ & 혈 & 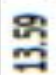 & $\begin{array}{l}\text { 요 } \\
\text { 응 }\end{array}$ & 竞 & 령 & 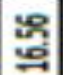 & 总 & 크 \\
\hline & & & $\begin{array}{l}5 \\
58 \\
5\end{array}$ & $\underset{m}{\stackrel{8}{m}}$ & ळ & 긍 & 冬 & 尽 & ষ্ণ & 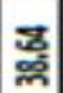 & 造 & 总 \\
\hline & & & 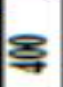 & 료 & 急 & $\overline{8}$ & : & 怘 & 궁 & ষ্̊ి & E & 尺) \\
\hline & & & $\bar{F}$ & 韋 & $\begin{array}{l}\mathbb{B} \\
\text { m }\end{array}$ & g8 & के & $\begin{array}{l}\text { 오 } \\
\text { 궁 }\end{array}$ & \$ & 运 & జ & ్ㅗㅇ \\
\hline & \multirow{4}{*}{ 貝 } & \multirow{4}{*}{ 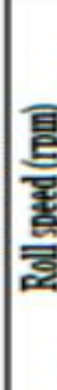 } & 8 & बై & 尽 & 류 & 刭 & $\begin{array}{l}\text { ॠ } \\
\approx\end{array}$ & $\underset{3}{3}$ & 욤 & $\stackrel{\approx}{\approx}$ & ణ \\
\hline & & & $\begin{array}{l}5 \\
8 \\
8\end{array}$ & 鸰 & 号 & 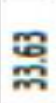 & జ & 况 & : & 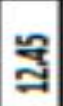 & 茎 & 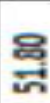 \\
\hline & & & 票 & $\stackrel{20}{0}$ & $\stackrel{2}{\approx}$ & 密 & 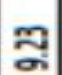 & 롱 & $\underset{\mathrm{B}}{\stackrel{8}{2}}$ & 8 & 욜 & ? \\
\hline & & & 蛋 & 言 & 疍 & \% & 능 & 을 & ฉี & $\begin{array}{l}8 \\
\text { 总 }\end{array}$ & 영 & $\frac{\mathrm{s}}{\mathrm{m}}$ \\
\hline वे & 氮 & & & 육 & ำ & 욜 & ㅇำ & ำ & 욨 & ำㄱำ & 육 & ำ \\
\hline & 聪 & & & & - & & & 3 & & & $\sigma$ & \\
\hline
\end{tabular}




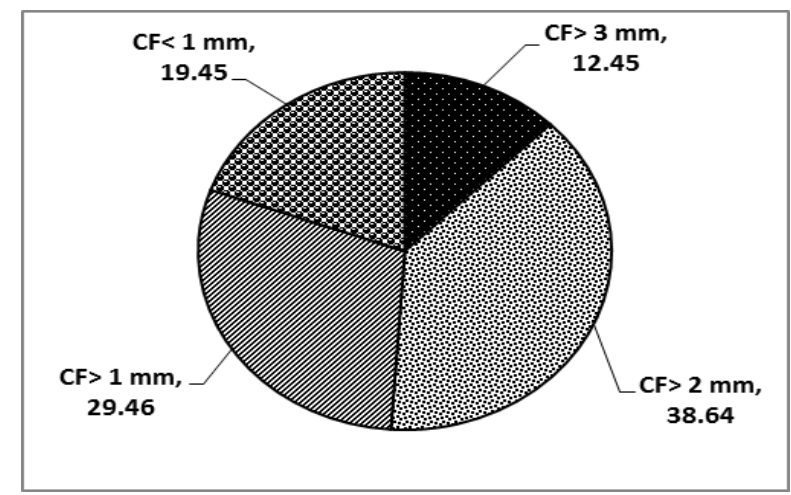

Fig.(7): The best distribution of the CF particle size for the starter.
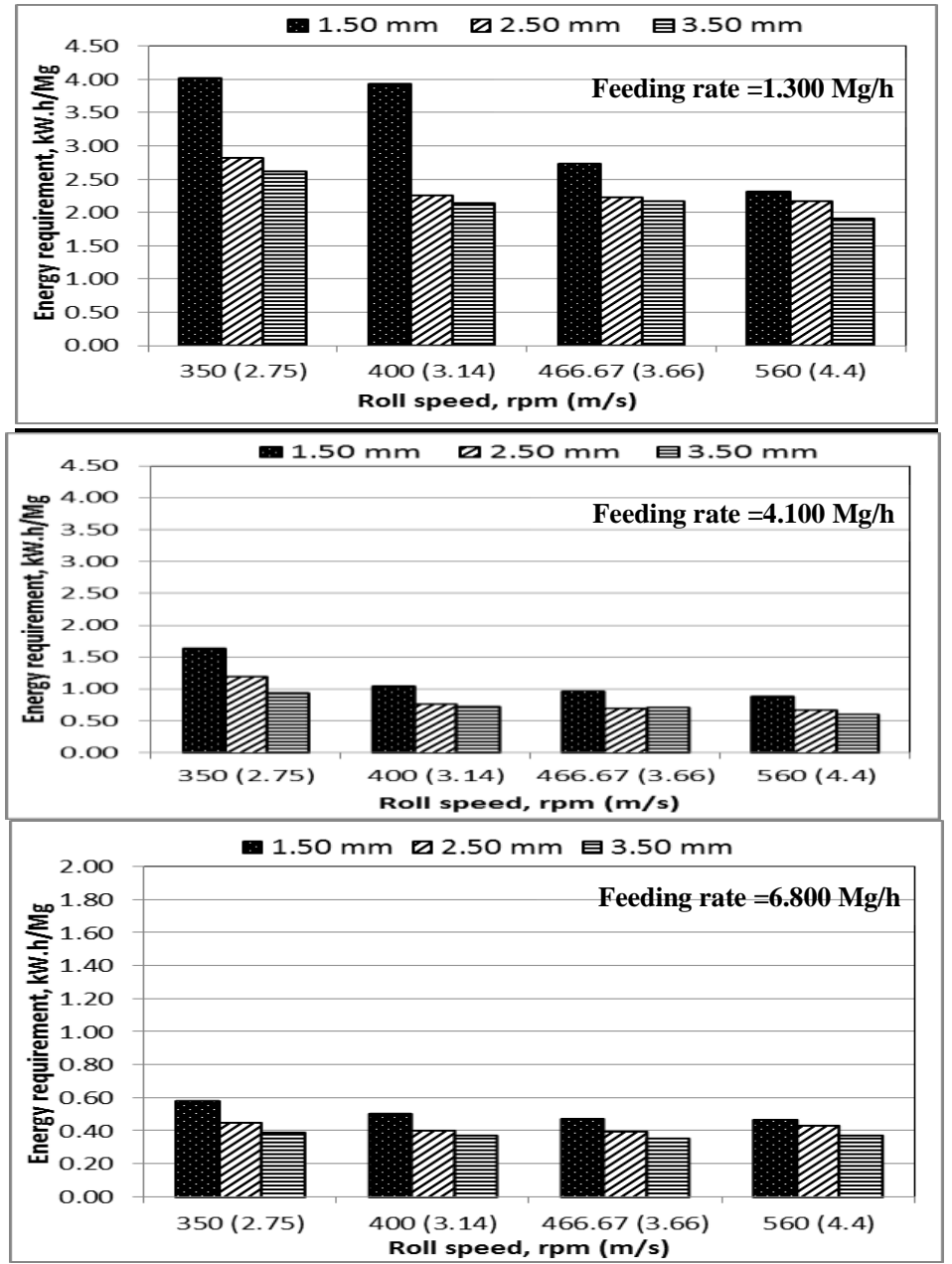

Fig.(8): Effect of rolls speed and feeding rate on the energy requirement under different roll clearances 
Generally, the lowest value of specific energy requirement of 0.380 $\mathrm{kW} . \mathrm{h} / \mathrm{Mg}$ was obtained at roll speed of $560 \mathrm{rpm}(4.40 \mathrm{~m} / \mathrm{s})$, feeding rate of $6.80 \mathrm{Mg} / \mathrm{h}$ and roll clearance of $3.50 \mathrm{~mm}$, while the highest value of specific energy requirement of $4.020 \mathrm{~kW} . \mathrm{h} / \mathrm{Mg}$ was obtained at roll speed of $350 \mathrm{rpm}(2.75 \mathrm{~m} / \mathrm{s})$, feeding rate of $1.300 \mathrm{Mg} / \mathrm{h}$ and roll clearance of $1.50 \mathrm{~mm}$. From previous discussion, it was found that, the corresponding energy requirement to the best $\mathrm{CF}$ particle size distribution (as displayed in Fig.7) of $0.476 \mathrm{~kW} . \mathrm{h} / \mathrm{Mg}$ was recorded at roll speed of $466.67 \mathrm{rpm}$ $(3.66 \mathrm{~m} / \mathrm{s})$, feeding rate of $6.80 \mathrm{Mg} / \mathrm{h}$ and roll clearance of $1.50 \mathrm{~mm}$ at machine capacity of $5.650 \mathrm{Mg} / \mathrm{h}$.

\section{CONCLUSION}

From this investigation, the obtained results revealed that, the proper conditions for operating the roller mill that used to produce crumbled feeds (CF) from poultry pellets were the roll speed of $466.67 \mathrm{rpm}$ (3.66 $\mathrm{m} / \mathrm{s}$ ), feeding rate of $6.800 \mathrm{Mg} / \mathrm{h}$ and roll clearance of $1.50 \mathrm{~mm}$ to achieve the best CF particle size distribution of $(<1 \mathrm{~mm}=19.45 \%, \geq 1 \mathrm{~mm}=$ $29.46 \%, \geq 2 \mathrm{~mm}=38.64 \%$ and $\geq 3 \mathrm{~mm}=12.45 \%$ ) that suit the broiler in the phase of starter as recommended by (Aviagen,2014) at machine capacity of $5.650 \mathrm{Mg} / \mathrm{h}$ and consumed energy of about $0.476 \mathrm{~kW} . \mathrm{h} / \mathrm{Mg}$.

\section{REFERENCES}

Aviagen (2014) ROSS Broiler Management Handbook: Provision Feed and Water, $30 \mathrm{pp}$.

Banerjee, G.C. (1998) Poultry. Third edition, Oxford and IBH Publishing Co. Pvt. Ltd., Calcutta, India, 120-121 pp.

Behnke, K.C. (1994) Factors Affecting Pellet Quality. Maryland Nutrition Conference, Department of Poultry Science and Animal Science, University of Maryland, College Park, Madison, USA.

Behnke, K.C. (1998) Why pellet? in Proceeding. of Kansas State University /Amer. Feed Industry Association Pellet Conference, Manhattan, Kansas, USA.

Dozier, W.A. (2002) Reducing utility cost in the feed mill. Watt Poultry USA, 53:40-44 pp.

Jahan, M. S.; M. Asaduzzaman and A.K. Sarkar (2006) Performance of broiler fed on mash, pellet and crumble. International Journal of Poultry Science, 5 (3): 265-270 pp. 
Mohamed, E.A. and E.A. Talha (2012) The effect of feeding pellets versus mash on performance and carcass characteristics of broiler chicks. Bull. Env. Pharmacol. Life Sci. Vol: 2 (2), www.bepls.com

Nir, I. and I. Ptichi (2001) Feed particle size and hardness: Influence on performance, nutritional, behavioral and metabolic aspects. In: Proceedings of the $1^{\text {st }}$ World Feed Conference, Utrecht, the Netherlands, 157-186 pp.

Nir, I.; R. Hillel; I. Ptichi and G. Shefet (1995) Effect of particle size on performance. 3: Grinding pelleting interactions. Poultry Science, 74: $771-783$ pp.

Waldroup, P.W. (1997) Particle size reduction of cereal grains and its significance in poultry nutrition. Technical Bulletin, American Soybean Association, Sinclearanceore, 14 pp.

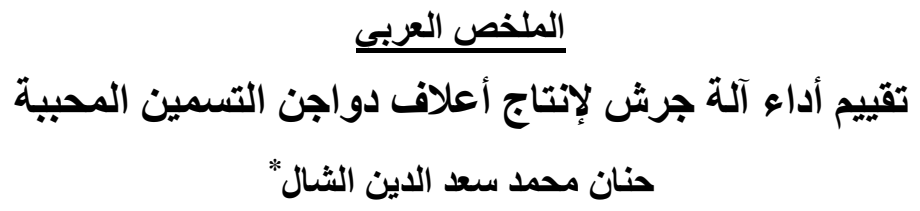

الهدف من هذة الدراسة هو تقييم بعض العوامل التشغيلية المؤثرة علي أداء آلة جرش أعلاف

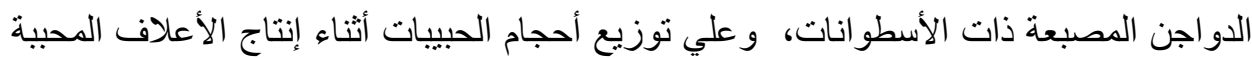

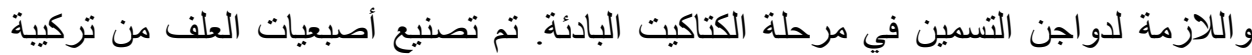
علفية تشمل المكونات و النسب الموصي بها لما لمرحلة كتاكيت التسمين البادئة. نم تقييم أداء الآلة

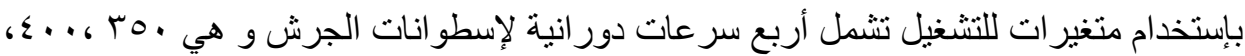

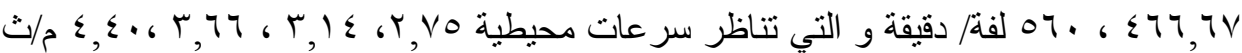

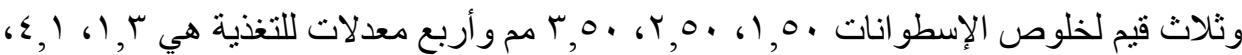

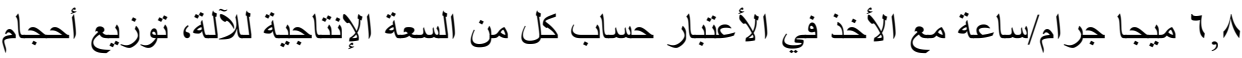

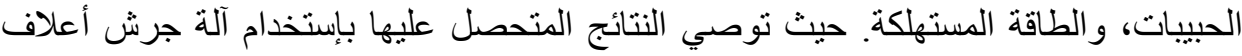

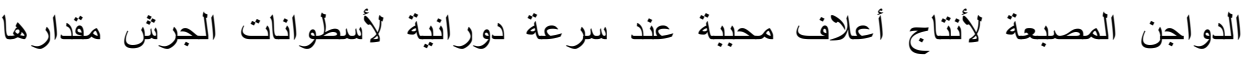

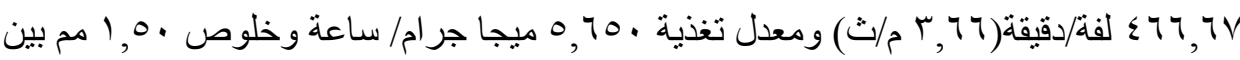

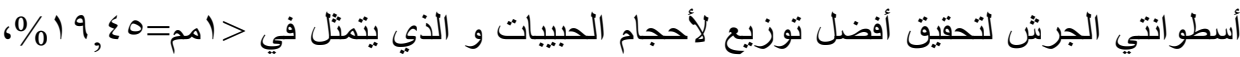

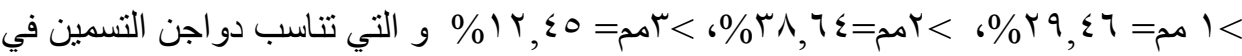

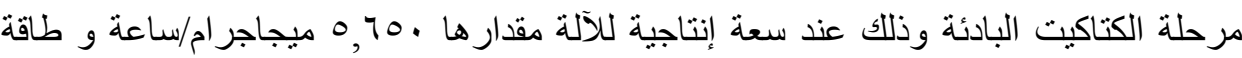

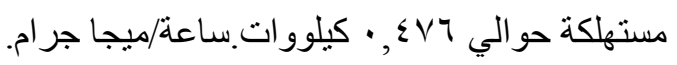

* مدرس الهندسة الزراعية ـ كلية الزراعة - جامعة الزقازيق- مصر. 